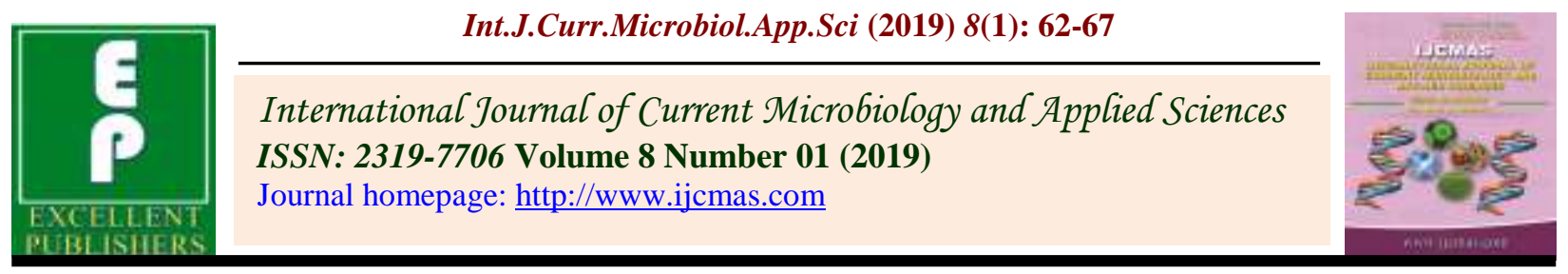

Original Research Article

https://doi.org/10.20546/ijcmas.2019.801.008

\title{
Correlation of Seed Germination with Various Weather Parameters under Different Environments in Upland Cotton (Gossypium hirsutum L.)
}

\author{
Pinki*, S.S. Siwach and Neha Rohila \\ CCS Haryana Agricultural University, Hisar, Haryana, India \\ *Corresponding author
}

A B S T R A C T

\begin{tabular}{|l|}
\hline Ke y w o r d s \\
Cotton, \\
Meteorological \\
Parameters, Seed \\
Germination, Different \\
environments, \\
Correlation
\end{tabular}

\section{Introduction}

Cotton is important commercial crop of India, highly sensitive crop to changes in temperature, humidity, and soil moisture, which may affect its yield, yield components and fiber properties. It is an important fiber yielding crop of global importance, which is grown in tropical and subtropical regions of more than 80 countries of the world.

It is an important fiber yielding crop of global importance, which is grown in tropical and subtropical regions of more than 80 countries of the world (Malagouda et al., 2014). India has a pride place in the global cotton scenario due to several distinct features such as the largest area under cotton (105 lakh ha) representing about one-third of the global cotton area (330 lakh ha) with production of $560 \mathrm{~kg} / \mathrm{ha}$ in the world ha (ICAR 2016-17). Weather is one of the important factors that affect crop growth. Crop productivity is directly influenced by temperature, rainfall, total radiation and photoperiod.

Environmental factors for optimum seed germination plays a vital role in realizing crop growth and yields. The time of sowings as 
varied growth condition for various crops differs depending on climate and varieties. Knowledge on effects of various elements of environment on crop growth, development and yield is important to harness good crop yield with better quality of seed and fiber (Ratnam et al., 2014).

The productivity of cotton has not made headway, therefore, there is a need to break plateau of yield potential by developing high yielding cotton varieties or hybrids. Yield is a complex trait, polygenic in inheritance and more prone to environmental fluctuations than other traits. In the presence of $G \times E$ interactions, selection based solely upon mean performance is insufficient for a single or range of environments (Singh et al., 2014). Cotton is not only our major fiber crop but also main source of edible oil, however, being ignored as an oilseed crop. Through developing the cotton varieties having both high fiber and oil yield, it would be possible to reduce edible oil imports in the country (Munawar et al., 2013). Genetic correlation measures the magnitude of cause-effect relationship between various traits that determine the component traits on which selection can be made. Thus, for the development of promising genotypes, the cotton breeder is obliged to study the breeding material regarding the nature and degree of correlations among seed cotton yield, its plant height, number of bolls, boll weight and ginning outturn under particular environmental conditions (Naveed et al., 2004).

Seed germination in cotton is a big problem under North Indian conditions. It remains much below the standard germination because of poor seed development and its quality is very much affected by environment. Sometimes seed germination in cotton may be reduced as low as $10 \%$ due to adverse environmental conditions and exact reasons for poor development of seed are not known. To overcome this problem correlation of seed germination (\%) and meteorological parameters were studied.

\section{Materials and Methods}

The experiment was conducted during kharif 2015 and 2016 having three cultivars H 1098I, H 1300 and H 1316 of upland cotton grown at CCS Haryana Agricultural University, Hisar in randomized block design replicated six times each in eight rows of $6 \mathrm{~m}$ length with a spacing of $67.5 \times 30 \mathrm{~cm}$. These varieties were grown in six environments that comprises of three sowings periods (Early: first fortnight of April, normal: first fortnight of May and late: end of May/early June) during the year 2015 and 2016 (Table 1).

Data was recorded as in all the three replications in every week flowers were tagged and number of effective bolls formed from these flowers was counted and the week in which maximum and minimum bolls developed was identified.

The seed cotton from these opened bolls was picked separately and ginned. This seed was used to test the seed quality parameters. These seed quality traits were correlated with different weather parameters to pin point the reasons for good or poor seed developments. The data on meteorological aspects was recorded from tagging period i.e. June, 24 to till the last picking of the experimental plots.

Meteorological data was recorded as:

Maximum and minimum temperature $\left({ }^{\circ} \mathrm{C}\right)$

Maximum and minimum temperature was calculated as the average temperature of different weeks and then averaged.

Relative humidity (\%) morning as well as 
evening

Relative humidity morning as well as evening was calculated as the average relative humidity of morning and evening of different tagging weeks and the averaged.

Sunshine hours

Sunshine hours were calculated as the average sunshine hours of different tagging weeks and the averaged.

Rainfall (mm) and number of rainy days

Rainfall and rainy days were calculated as the total rainfall and number of rainy days of different weeks and then finally total all the rainfall and number of rainy days of the tagging weeks.

\section{Results and Discussion}

Weakly meteorological data for seed development period in 2015 is presented in table 2. During 2015 flowering started from $28^{\text {th }}$ June and it continued up to August 29. The fresh opened flowers were tagged daily and their number was recorded on weekly basis for 10 weeks. The number of tagged flowers maturing in to well-developed open bolls was the number of retained bolls. These bolls were picked weekly and their number was counted, ginned and same were used for further tests like germination and biochemicals.

These results were correlated with different weather parameters. Data on weather parameters i.e. Temperature (Max. and Min.) or ( $\mathrm{T}_{\max }$ and $\mathrm{T}_{\text {min) }}$, Relative humidity (morning and evening) or $\left(\mathrm{RH}_{\mathrm{m}}\right.$ and $\left.\mathrm{RH}_{\mathrm{e}}\right)$, sunshine hours $(\mathrm{SS})$, rainfall $(\mathrm{RF})$ and rainy days $(\mathrm{RD})$ were recorded for these 10 weeks (Table 2). Range for $\mathrm{T}_{\max }$ during these 10 weeks was $33.0-37.8$, for $\mathrm{T}_{\min }$ it was $23.9-26.8$, for $\mathrm{RH}_{\mathrm{m}}$ was $72.4-$ 92.7, for $\mathrm{RH}_{\mathrm{e}}$ was 40.3 - 75.0, for sunshine hours was $2.6-9.5$, for rainfall was $0-77.3$ and for rainy days was $0-4$ during these weeks. Mean $\mathrm{T}_{\max }$ for these 10 weeks was $34.9^{\circ} \mathrm{C} \mathrm{T}_{\text {min }}$ was $25.8^{\circ} \mathrm{C}, \mathrm{RH}_{\mathrm{m}}$ was $85.4 \%, \mathrm{RH}_{\mathrm{e}}$ was $60.7 \%$, sunshine hours were 6.4 hours, rainfall was $220.6 \mathrm{~mm}$ and rainy days were 16 .

Weakly meteorological data for seed development period in 2016 is presented in table 3. During the year 2016 also data were recorded in similar way as that of 2015 starting from June 24 to Sept. 1. Temperature (Max. and Min.) or $\left(\mathrm{T}_{\max }\right.$ and $\mathrm{T}_{\min }$ ), Relative humidity (morning and evening) or $\left(\mathrm{RH}_{\mathrm{m}}\right.$ and $\mathrm{RH}_{\mathrm{e}}$ ), sunshine hours (SS), rainfall (RF) and rainy days $(\mathrm{RD})$ were recorded for these 10 weeks (Table 3).

Table.1 Sowing dates and different environments in 2015 and 2016

\begin{tabular}{|c|c|c|c|}
\hline \multirow{2}{*}{ Year } & Environment & Date of Sowing & $\begin{array}{c}\text { Environment } \\
\text { Designation }\end{array}$ \\
\hline \multirow{2}{*}{ So15 } & Early & 10 April & $\mathrm{E}_{1}$ \\
\cline { 2 - 4 } & Normal & $15 \mathrm{May}$ & $\mathrm{E}_{2}$ \\
\cline { 2 - 4 } & Late & $5 \mathrm{June}$ & $\mathrm{E}_{3}$ \\
\hline \multirow{2}{*}{2016} & Early & $26 \mathrm{April}$ & $\mathrm{E}_{4}$ \\
\cline { 2 - 4 } & Normal & $5 \mathrm{May}$ & $\mathrm{E}_{5}$ \\
\cline { 2 - 4 } & Late & 2 June & $\mathrm{E}_{6}$ \\
\hline
\end{tabular}


Table.2 Weakly meteorological data for seed development period during 2015

\begin{tabular}{|c|c|c|c|c|c|c|c|c|c|}
\hline \multirow[b]{2}{*}{2015} & \multirow[b]{2}{*}{$\begin{array}{l}\text { Tagging } \\
\text { period }\end{array}$} & \multirow[b]{2}{*}{ Picking } & \multicolumn{2}{|c|}{$\begin{array}{l}\text { Temperatu } \\
\text { re }\left({ }^{\circ} \mathbf{C}\right)\end{array}$} & \multicolumn{2}{|c|}{$\begin{array}{c}\text { Relative humidity } \\
\%\end{array}$} & \multirow[t]{2}{*}{$\begin{array}{c}\text { SS } \\
\text { (hrs) }\end{array}$} & \multirow[t]{2}{*}{$\begin{array}{c}\text { Rainfall } \\
(\mathbf{m m})\end{array}$} & \multirow[t]{2}{*}{$\begin{array}{c}\text { Rainy } \\
\text { days }\end{array}$} \\
\hline & & & $\mathbf{T}_{\max }$ & $\mathbf{T}_{\min }$ & Morning & Evening & & & \\
\hline 1 & 28-June-4 July & 1-Sep & 37.8 & 25.8 & 80.1 & 48.1 & 8.3 & 15.8 & 2.0 \\
\hline 2 & 5-July- 11 july & 7-Sep & 34.0 & 26.1 & 86.1 & 70.7 & 2.8 & 46.7 & 1.0 \\
\hline 3 & $\begin{array}{l}\text { 12-July- } 18 \\
\text { July }\end{array}$ & 13-Sep & 33.5 & 26.3 & 86.0 & 63.7 & 6.0 & 24.7 & 2.0 \\
\hline 4 & $\begin{array}{l}\text { 19-July- } 25 \\
\text { July }\end{array}$ & 20-Sep & 35.6 & 26.7 & 87.3 & 63.0 & 7.3 & 77.3 & 1.0 \\
\hline 5 & 26-July- 1 Aug & 25-Sep & 33.0 & 25.4 & 88.9 & 71.0 & 7.0 & 2.9 & 1.0 \\
\hline 6 & 2-Aug- 8 Aug & $2-\mathrm{Oct}$ & 33.7 & 26.0 & 90.0 & 62.7 & 4.2 & 7.4 & 2.0 \\
\hline 7 & 9-Aug-15 Aug & 9-Oct & 34.3 & 26.8 & 92.7 & 75.0 & 2.6 & 29.2 & 4.0 \\
\hline 8 & 16-Aug-22 Aug & 13 -Oct & 34.2 & 26.1 & 88.1 & 57.7 & 6.9 & 7.8 & 2.0 \\
\hline 9 & 23-Aug-29 Aug & $20-$ Oct & 36.2 & 25.6 & 82.0 & 55.0 & 9.3 & 8.8 & 1.0 \\
\hline \multirow[t]{2}{*}{10} & 30-Aug-6Oct & $27-$ Oct & 37.0 & 23.9 & 72.4 & 40.3 & 9.5 & 0.0 & 0.0 \\
\hline & & & 34.9 & 25.8 & 85.4 & 60.7 & 6.4 & 220.6 & 16.0 \\
\hline
\end{tabular}

Table.3 Weakly meteorological data for seed development during period 2016

\begin{tabular}{|c|c|c|c|c|c|c|c|c|c|}
\hline \multirow[b]{2}{*}{2016} & \multirow[b]{2}{*}{$\begin{array}{l}\text { Tagging } \\
\text { Period }\end{array}$} & \multirow[b]{2}{*}{ Picking } & \multicolumn{2}{|c|}{$\begin{array}{c}\text { Temperature } \\
\left({ }^{\circ} \mathrm{C}\right)\end{array}$} & \multicolumn{2}{|c|}{$\begin{array}{c}\text { Relative humidity } \\
\%\end{array}$} & \multirow[t]{2}{*}{$\begin{array}{c}\text { SS } \\
(\mathbf{h r s})\end{array}$} & \multirow[t]{2}{*}{$\begin{array}{c}\text { Rainfall } \\
(\mathbf{m m})\end{array}$} & \multirow[t]{2}{*}{$\begin{array}{l}\text { Rainy } \\
\text { days }\end{array}$} \\
\hline & & & $\mathbf{T}_{\max }$ & $\mathbf{T}_{\min }$ & Morning & Evening & & & \\
\hline 1 & $\begin{array}{l}\text { 24-June- } 30 \\
\text { June }\end{array}$ & 28-Aug & 38.0 & 28.0 & 74.7 & 58.3 & 6.7 & 13.0 & 1.0 \\
\hline 2 & 1-July- 7 July & 4-Sep & 35.1 & 26.5 & 90.4 & 71.3 & 5.8 & 93.5 & 3.0 \\
\hline 3 & 8-July- 14 July & 11-Sep & 36.3 & 27.2 & 86.6 & 72.3 & 7.3 & 4.0 & 1.0 \\
\hline 4 & $\begin{array}{l}\text { 15-July- } 21 \\
\text { July }\end{array}$ & 18-Sep & 33.9 & 25.3 & 91.9 & 71.3 & 4.5 & 73.3 & 5.0 \\
\hline 5 & $\begin{array}{l}\text { 22-July- } 28 \\
\text { July }\end{array}$ & 23-Sep & 36.7 & 26.0 & 89.4 & 70.4 & 8.0 & 27.0 & 1.0 \\
\hline 6 & 29-July- 4 Aug & 30-Sep & 32.5 & 25.2 & 93.4 & 74.4 & 4.2 & 47.0 & 1.0 \\
\hline 7 & 5-Aug- 11 Aug & 7-Oct & 34.6 & 26.1 & 91.6 & 75.7 & 6.0 & 4.3 & 1.0 \\
\hline 8 & $\begin{array}{l}\text { 12-Aug- } 18 \\
\text { Aug }\end{array}$ & $11-O c t$ & 34.8 & 24.7 & 85.7 & 60.3 & 6.5 & 4.5 & 1.0 \\
\hline 9 & $\begin{array}{l}\text { 19-Aug-25 } \\
\text { Aug }\end{array}$ & 15 -Oct & 34.0 & 26.4 & 88.1 & 61.1 & 5.1 & 8.4 & 2.0 \\
\hline 10 & 26-Aug- 1 Sept & 19-Oct & 32.8 & 25.3 & 94.4 & 77.7 & 6.0 & 63.2 & 2.0 \\
\hline & & & 34.9 & 26.1 & 88.6 & 69.3 & 6.0 & 338.2 & 18.0 \\
\hline
\end{tabular}


Table.4 Correlation of seed germination (\%) with various weather parameters under different environments in H 1098- I

\begin{tabular}{|c|c|c|c|c|c|c|}
\hline & & & & H 1098-I & & \\
\hline & $\mathrm{E}_{1}$ & $\mathrm{E}_{2}$ & $\mathrm{E}_{3}$ & $\mathrm{E}_{4}$ & $\mathrm{E}_{5}$ & $\mathrm{E}_{6}$ \\
\hline $\mathbf{T}_{\mathbf{m a x}}$ & $-0.78^{*}$ & $-0.74^{*}$ & $-0.72^{*}$ & -0.13 & 0.28 & 0.27 \\
\hline $\mathbf{T}_{\mathbf{m i n}}$ & $0.73^{*}$ & $0.71^{*}$ & $0.70^{*}$ & -0.28 & 0.09 & 0.10 \\
\hline $\mathbf{R H}_{\mathbf{m}}$ & $0.88^{*}$ & $0.85^{*}$ & $0.85^{*}$ & 0.40 & 0.14 & 0.08 \\
\hline $\mathbf{R} \mathbf{H}_{\mathbf{e}}$ & $0.88^{*}$ & $0.89^{*}$ & $0.89^{*}$ & 0.47 & 0.40 & 0.33 \\
\hline $\mathbf{S S}$ & $-0.75^{*}$ & $-0.81^{*}$ & $-0.84^{*}$ & -0.05 & 0.06 & 0.03 \\
\hline $\mathbf{R F}$ & 0.45 & 0.42 & 0.39 & -0.16 & 0.00 & -0.10 \\
\hline $\mathbf{R D}$ & 0.48 & $0.60^{*}$ & $0.62^{*}$ & -0.06 & -0.08 & -0.13 \\
\hline
\end{tabular}

$\mathrm{T}_{\max }=$ Maximam Temperature $\quad \mathrm{T}_{\min }=$ Minimum Temperature $\quad \mathrm{RH}_{\mathrm{m}}=$ Morning Relative Humidity $\mathrm{RH}_{\mathrm{e}}=$ Evening Relative HumiditySS = Sunshine; RF = Rainfall $\mathrm{RD}=$ Rainy Days

Table.5 Correlation of seed germination (\%) with various weather parameters under different environments in $\mathrm{H} 1300$

\begin{tabular}{|c|c|c|c|c|c|c|}
\hline & & & H 1300 & & & \\
\hline & $\mathrm{E}_{1}$ & $\mathrm{E}_{2}$ & $\mathrm{E}_{3}$ & $\mathrm{E}_{4}$ & $\mathrm{E}_{5}$ & $\mathrm{E}_{6}$ \\
\hline $\mathbf{T}_{\mathbf{m a x}}$ & $-0.75^{*}$ & $-0.76^{*}$ & $-0.72^{*}$ & -0.15 & 0.25 & 0.13 \\
\hline $\mathbf{T}_{\mathbf{m i n}}$ & $0.69^{*}$ & $0.70^{*}$ & $0.70^{*}$ & -0.28 & 0.12 & -0.05 \\
\hline $\mathbf{R H}_{\mathbf{m}}$ & $0.86^{*}$ & $0.84^{*}$ & $0.84^{*}$ & 0.41 & -0.01 & -0.04 \\
\hline $\mathbf{R H}_{\mathbf{e}}$ & $0.89^{*}$ & $0.89^{*}$ & $0.89^{*}$ & 0.47 & 0.18 & 0.00 \\
\hline $\mathbf{S S}$ & $-0.78^{*}$ & $-0.80^{*}$ & $-0.82^{*}$ & -0.07 & -0.02 & -0.12 \\
\hline $\mathbf{R F}$ & 0.42 & 0.41 & 0.42 & -0.15 & -0.24 & -0.32 \\
\hline $\mathbf{R D}$ & 0.50 & 0.59 & $0.61^{*}$ & -0.09 & -0.20 & -0.26 \\
\hline
\end{tabular}

$\mathrm{T}_{\max }=$ Maximam Temperature $\mathrm{T}_{\min }=$ Minimum Temperature $\mathrm{RH}_{\mathrm{m}}=$ Morning Relative Humidity $\mathrm{RH}_{\mathrm{e}}=$ Evening Relative HumiditySS= Sunshine; RF = Rainfall $\mathrm{RD}=$ Rainy Days

Table.6 Correlation of seed germination (\%) with various weather parameters under different environments in $\mathrm{H} 1316$

\begin{tabular}{|c|c|c|c|c|c|c|}
\hline & & & H 1316 & & & \\
\hline & $\mathrm{E}_{1}$ & $\mathrm{E}_{2}$ & $\mathrm{E}_{3}$ & $\mathrm{E}_{4}$ & $\mathrm{E}_{5}$ & $\mathrm{E}_{6}$ \\
\hline $\mathbf{T}_{\mathbf{m a x}}$ & $-0.77^{*}$ & $-0.75^{*}$ & $-0.74^{*}$ & -0.14 & 0.28 & 0.20 \\
\hline $\mathbf{T}_{\mathbf{m i n}}$ & $0.68^{*}$ & $0.70^{*}$ & $0.69^{*}$ & -0.30 & 0.03 & -0.06 \\
\hline $\mathbf{R H}_{\mathbf{m}}$ & $0.85^{*}$ & $0.84^{*}$ & $0.84^{*}$ & 0.41 & -0.09 & 0.06 \\
\hline $\mathbf{R H}$ & $0.89^{*}$ & $0.89^{*}$ & 0.89 & 0.46 & 0.10 & 0.21 \\
\hline $\mathbf{S S}$ & $-0.77^{*}$ & $-0.81^{*}$ & $-0.82^{*}$ & -0.03 & 0.01 & 0.02 \\
\hline $\mathbf{R F}$ & 0.45 & 0.40 & 0.39 & -0.20 & -0.28 & -0.21 \\
\hline $\mathbf{R D}$ & 0.46 & 0.60 & $0.61^{*}$ & -0.09 & -0.22 & -0.29 \\
\hline
\end{tabular}

$\mathrm{T}_{\max }=$ Maximam Temperature $\mathrm{T}_{\min }=$ Minimum Temperature $\quad \mathrm{RH}_{\mathrm{m}}=$ Morning Relative Humidity $\mathrm{RH}_{\mathrm{e}}=$ Evening Relative HumiditySS= Sunshine; RF = Rainfall $\mathrm{RD}=$ Rainy Days 
Range for $\mathrm{T}_{\max }$ during these 10 weeks was 32.5 - 38, for $\mathrm{T}_{\text {min }}$ it was $24.7-28.0$, for $\mathrm{RH}_{\mathrm{m}}$ was 74.7 - 94.4, for $\mathrm{RH}_{\mathrm{e}}$ was 58.3 - 77.7, for sunshine hours was $4.2-8.0$, for rainfall was 4 - 95.5 and $1-5$ rainy days for these weeks. Mean $\mathrm{T}_{\max }$ for these 10 weeks was $34.9^{\circ} \mathrm{C}, \mathrm{T}_{\min }$ was $26.1{ }^{\circ} \mathrm{C}, \mathrm{RH}_{\mathrm{m}}$ was $88.6 \%, \mathrm{RH}_{\mathrm{e}}$ was $69.3 \%$, sunshine hours were 6 hours, rainfall was 338.2 $\mathrm{mm}$ and rainy days were 18 .

Correlation of seed germination (\%) with weather parameters was shown in Tables 4, 5 and 6 . In the variety $\mathrm{H}$ 1098- I seed germination in $E_{1}, E_{2}$ and $E_{3}$ was negatively correlated with maximum temperature $\left(\mathrm{T}_{\max }\right)$. Seed germination in $E_{1}, E_{2}$ and $E_{3}$ was positively correlated with minimum temperature $\left(\mathrm{T}_{\min }\right)$, relative humidity morning and evening $\left(\mathrm{RH}_{\mathrm{m}}\right.$ and $\left.\mathrm{RH}_{\mathrm{e}}\right)$. Seed germination in $E_{1}, E_{2}$ and $E_{3}$ was negatively correlated with sunshine hours (SS). Seed germination in $E_{2}$ and $E_{3}$ was positively correlated with rainy days (RD).

In the variety $H 1300$ and $H 1316$ seed germination in $\mathrm{E}_{1}, \mathrm{E}_{2}$ and $\mathrm{E}_{3}$ was negatively correlated with $\mathrm{T}_{\max }$. Seed germination in E1, E2 and E3 were positively correlated with $T_{\min }$, $\mathrm{RH}_{\mathrm{m}}$ and $\mathrm{RH}_{\mathrm{e}}$ whereas, negatively correlated with Sunshine hours (SS). Seed germination in E3 was positively correlated with rainy days (RD).

The inclusion of various yield component characters in a selection scheme is obviously not practicable and under these situations, knowledge with respect to the association of various traits with yield would be of immense help in formulating an effective and efficient selection programme.

\section{References}

ICAR-All India Coordinated Research Project on Cotton Annual Report 2016-2017.

Malagouda, P. Khadi, B.M. Basamma, K. and I.S. Katageri (2014). Genetic variability and correlation analysis for fibre quality traits in diploid cotton (Gossypium spp). J. Agric. \& Environ. Sci. 14 (5): 392-395.

Munawar, M. and Malik, T.A. (2013). Correlation and genetic architecture of seed traits and oil content in Gossypium hirsutum L. J. Plant Breed. Genet. 1(02): 56-61.

Naveed, M., Azhar, F.M. and Ali, A. (2004). Estimates of heritabilities and correlations among seed cotton yield and its components in Gossypium hirsutum L. Int. J. Agri. Biol. 6(4): 712-714.

Naveed, M., Azhar, F.M. and Ali, A. (2004). Estimates of heritabilities and correlations among seed cotton yield and its components in Gossypium hirsutum L. Int. J. Agri. Biol. 6(4): 712-714.

Preetha, S. and Raveendran, T.S. (2007). Genetic variability and association analysis in three different morphological groups of cotton (Gossypium hirsutum L.). Asian J.Pl. Sci. 6(1): 122-128.

Ratnam, M., Reddy, S.K., Bharathi, S. (2014). Influence of weather parameters on growth and yield of $\mathrm{Bt}$ cotton under krishina agro climatic zone of Andhra Pradesh. J. Cotton Res. Dev. 28(2): 214216.

Singh, S., Singh, V.V. and Choudhary, A.D. (2014). Genotype $\times$ Environment interaction and yield stability in multienvironment. Tropical subtrop. Agroeco. 17: 477-482.

\section{How to cite this article:}

Pinki, S.S. Siwach and Neha Rohila. 2019. Correlation of Seed Germination with Various Weather Parameters under Different Environments in Upland Cotton (Gossypium hirsutum L.). Int.J.Curr.Microbiol.App.Sci. 8(01): 62-67. doi: https://doi.org/10.20546/ijcmas.2019.801.008 